\title{
Exploration of Physics-Chemical Quality Lahor Reservoir of Malang District, Indonesia
}

\author{
H. Setyobudiarso ${ }^{1}$, E. Yuwono ${ }^{2}$ \\ ${ }^{1}$ Enviroment Engineering Dept, National Institute of Technology Malang \\ ${ }^{2}$ Civil Engineering Dept, Institut Teknologi Nasional Malang \\ Email: hery_sba@yahoo.com
}

\begin{abstract}
Lahor Reservoir was built and functioned as a water provider for agricultural activities, flood control, electricity generation, tourism activities and inland fisheries. This reservoir is one of the inflows of the Sutami reservoir which is the largest reservoir in East Java. This Lahor Reservoir is drained by three rivers, namely the Lahor River, Leso River and the Dewi River, which flows through housing and paddy fields, allowing the entry of organic and inorganic materials from various activities around the rivers and reservoirs. The aim of the study was to assess the physico-chemical parameters of the Lahor reservoir during the dry season. This research was conducted between March and April 2018. Water quality analysis was carried out in the Laboratory of Environmental Engineering Department of ITN Malang. The study was conducted by survey method and sampling method. Measurement of physical and chemical parameters of the waters was determined at 4 stations and each station consisted of 5 sampling points with different depths. Data analysis using descriptive statistics (mean, graph). The assessment of the temperature in the waters of the Lahor Dam ranged from a value of 24-28 ${ }^{\circ} \mathrm{C}$, turbidity with a value of $0.4 \mathrm{NTU}$, DO values from surface to base increased significantly with values of $29.1 \mathrm{mg} / \mathrm{L}, 33.9 \mathrm{mg} / \mathrm{L}$ and $34.3 \mathrm{mg} / \mathrm{L}$ and still meet the minimum water requirements for aquaculture. The high BOD value at the Lahor reservoir outlet is influenced by the accumulation of organic substances from several inlets and dam waters. Phosphate values are higher along with water depth and Fecal Coli ranges from 1$2 \mathrm{MPN} / 100 \mathrm{~mL}$ at all sampling points. In general, the Lahor reservoir water still meets the quality standards for class I waters.
\end{abstract}

Keywords: Reservoir, Physic-Chemical parameter, organic, anorganic, sampling point Paper type: Research paper

\section{INTRODUCTION}

Freshwater waters, one of them is a reservoir, occupying a smaller space compared to the sea or land. However, freshwater ecosystems have a very important role because they are cheap domestic and industrial water sources. Reservoir is one of the artificial freshwater which is made by damming certain rivers which are needed as a flood prevention media and power plants. The existence of reservoirs also provides benefits to surrounding communities as water providers for agricultural irrigation needs, karamba fishing activities and also for tourism. The reservoir receives continuous water input from the river flowing and has different characteristics from other water bodies.

The Lahor Reservoir, which was built in 1972 and has been operating since November 1977, is part of the Brantas watershed development project which has an area of $2.6 \mathrm{~km} 2$ which is located approximately $1.5 \mathrm{~km}$ north of Sutami Dam, and approximately $32 \mathrm{~km}$ south of Malang city, in the Blitar Regency area.

The Lahor Reservoir was built with the aim of providing water to drain agricultural land, control floods, power plants, tourism activities and bargain aquaculture. In addition, it is also one of the inlet (inflow areas) of the Sutami reservoir which is the largest reservoir in East Java. This Lahor Reservoir is drained by three rivers, namely the Lahor River, Leso River and Dewi River, which allow the quality of the water to be mixed with organic and inorganic materials derived from various activities around the reservoir and the rivers. This input load will stimulate the process of nutrient enrichment (eutrophication), which enriches the nutrient content of the waters so that it can trigger excessive growth (blooming) of certain types of phytoplankton.

The waters experience phytoplankton blooms if the abundance of phytoplankton reaches 5 x 106 cells / liter [1] Therefore, in order to maintain the sustainability of the Lahor reservoir waters and to benefit human interests, it is necessary to examine the management of the reservoir's aquatic environment by maintaining the physical, chemical and biological quality of the waters. 


\section{METHOD}

\section{Location and Time of research}

This research was conducted in the waters of the Lahor reservoir in Blitar Regency. Sampling is carried out 5 times in the dry season with an interval of one month between March and April 2018. Analysis of water quality is carried out in the Laboratory of Environmental Engineering Department of ITN Malang. The study was conducted by survey method and sampling method. Measurement of physical and chemical parameters of the waters was determined at 4 stations and each station consisted of 5 sampling points with different depths and data analysis using Descriptive Statistics.

\begin{tabular}{llc}
\hline \multicolumn{1}{c}{ Station to collect sample } & Sampling point \\
\hline Station I $:$ Around the reservoir inlet & Sampling point I \\
Station II $:$ Edge of reservoir & Sampling point II \\
Station III : Middle of the reservoir & Sampling point III \\
Station IV : Around the reservoir outlet & Sampling point IV \\
\hline
\end{tabular}

\section{Determination of Sampling Points}

Determination of the point and depth of sampling was carried out at several points estimated to represent the Lahor Dam with variations in depths of $0 \mathrm{~m}, 5 \mathrm{~m}$, and $10 \mathrm{~m}$. Determination of sampling points is based on SNI 6989.57: 2008 concerning Method of sampling surface water. The measurement parameters and methods are listed in Table 1 below.

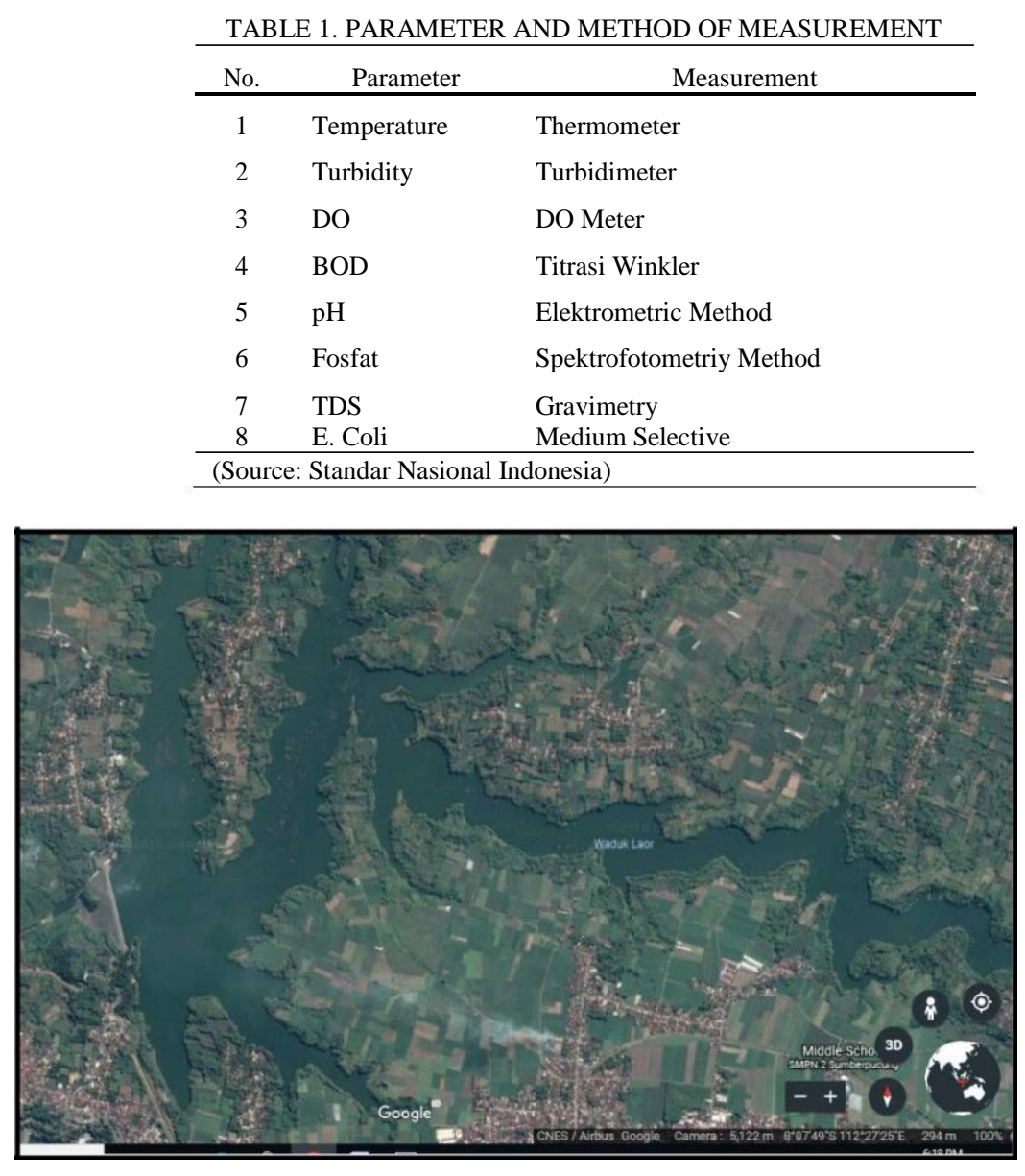

Figure 2. Map of Lahor Dam

\section{DISCUSSION}

The temperature in the waters of the Lahor Dam ranges from $24-28{ }^{\circ} \mathrm{C}$. The optimum temperature range for phytoplankton growth in waters is $20-30{ }^{\circ} \mathrm{C}$ [2]. While for fisheries the optimum temperature ranges from $24-30$ 
Exploration of Physics-Chemical Quality Lahor Reservoir of Malang District, Indonesia

${ }^{\circ} \mathrm{C}$ [12]. The following is a picture of the results of measurements of the water temperature of the Lahor Dam which are presented in graphical form as shown in Figure 3.

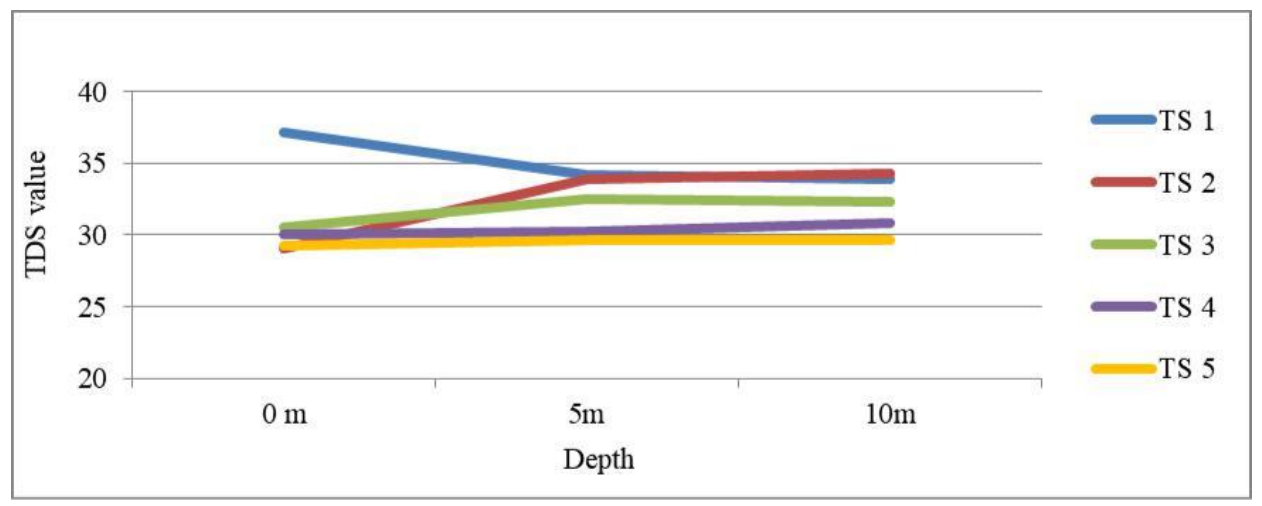

Fig. 3. Temperature Value Measurement

The water temperature in the Lahor Dam when viewed from the value presented in the form of the graph above, the deeper the sampling point, the lower the measured temperature value. Temperature in the waters can be influenced by time, weather and point depth during sampling. The brightness level in the waters can be influenced by the intensity of sunlight and the turbidity level of a waters. If the turbidity value of a high water will block the intensity of sunlight that will enter into a waters. Brightness values will affect the interaction of organisms in the water will be converted into heat energy [3]. Water temperature can affect the primary productivity of the waters, with increasing temperatures that can still be tolerated by plant microorganisms, will be followed by an increase in the degree of metabolism and photosynthetic activity in it [4].

Temperature has an important effect in terms of water productivity. The combination of temperature and increased nutrient content arising from this mixing will increase the productivity of the waters. Increasing temperatures in the waters are also followed by increased toxicity of many dissolved contaminants in addition to increasing oxygen consumption. Temperature will also affect Nitrate and Phosphate in waters, this is possible because the lower the temperature, the higher the content of Nitrate and Phosphate [5].

Based on Figure 3 the results of measuring Turbidity values in the waters of the Lahor Dam, the highest value is at point I with a value between 2 NTU - 2.8 NTU. The value of Turbidity obtained from the measurement results obtained an increasingly greater value at a depth of $5 \mathrm{~m}$ and $10 \mathrm{~m}$. While the lowest value is at point $\mathrm{V}$ on the surface with a value of $0.4 \mathrm{NTU}$.

Turbidity can be caused by suspended or dissolved particles from soil particles, organic and inorganic materials, algae and other microscopic organisms [6]. Turbidity that occurs in reservoir waters or dams is caused by the entry of organic and inorganic substances and suspended sediments which are carried into the waters of the dam through the surrounding river flows. Another source according to [7], namely the use of fertilizers, pesticides in agricultural activities and feed from fish. The high level of turbidity in a waters causes a reduction in aesthetics which affects the condition of the reservoir for utilization. High turbidity will also interfere with the penetration of sunlight into the waters. Reduced sunlight entering the waters disrupts photosynthesis and decreases the brightness of the waters of the Dam. In addition, high turbidity also prevents the entry of oxygen into the water so that it disturbs the life of aquatic biota. Organic particles will be degraded by decomposing microorganisms [6].

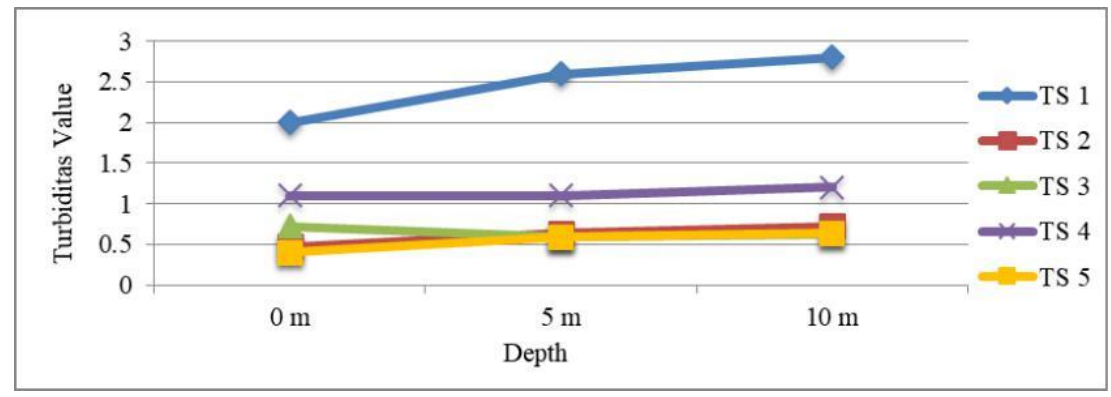

Fig. 3. Turbidity Value Measurement 
The results of the analysis of the content of Total Dissolved Solid (TDS) in the waters of the Lahor Dam found values ranging from $29.3 \mathrm{mg} / \mathrm{L}-37.2 \mathrm{mg} / \mathrm{L}$.

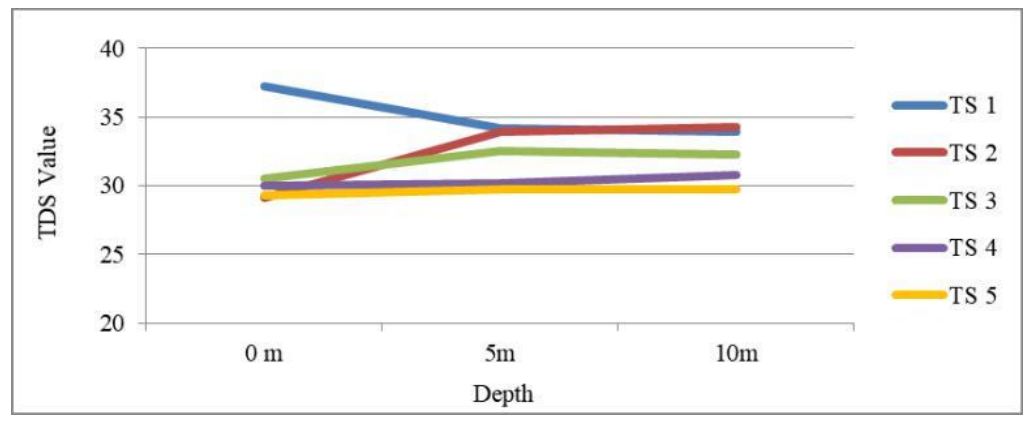

Fig. 4. TDS Value Measurement

Based on Figure 4, the highest TDS value was found at sampling point I with a value of $37.2 \mathrm{mg} / \mathrm{L}$ at a depth of $0 \mathrm{~m}$, while the lowest TDS value was found at sampling point II at a depth of $0 \mathrm{~m}$ with a value of 29.1 $\mathrm{mg} / \mathrm{L}$. The trend of TDS values obtained from the analysis results fluctuated at each sampling point with depth variations. At point I the TDS value on the surface is higher than the TDS value at $5 \mathrm{~m}$ and $10 \mathrm{~m}$ depth. while the other four sampling points increased in value from a surface of $0 \mathrm{~m}$ to a depth of $10 \mathrm{~m}$. At sampling point II, the increase in value from the surface to the base increased significantly with a value of $29.1 \mathrm{mg} / \mathrm{L}, 33.9 \mathrm{mg} / \mathrm{L}$ and $34.3 \mathrm{mg} / \mathrm{L}$.

High concentrations of TDS in waters will cause high turbidity values. This is caused by the concentration of dissolved solids in the water will change the color of the water to be darker. The main sources for TDS in waters are abundance from agriculture, household waste, and industry. Changes in the concentration of TDS can be dangerous because it will cause a decrease in the level of water brightness, changes in salinity, changes in the composition of ions, and the toxicity of each ion. Changes in salinity can disturb the balance of aquatic biota, biodiversity, cause species that are less tolerant, and cause high toxicity at the life stages of an organism [8].

Measurement of Dissolved Oxygen levels in Lahor Dam is carried out directly using the DO Meter tool shown as shown in Figure 5.

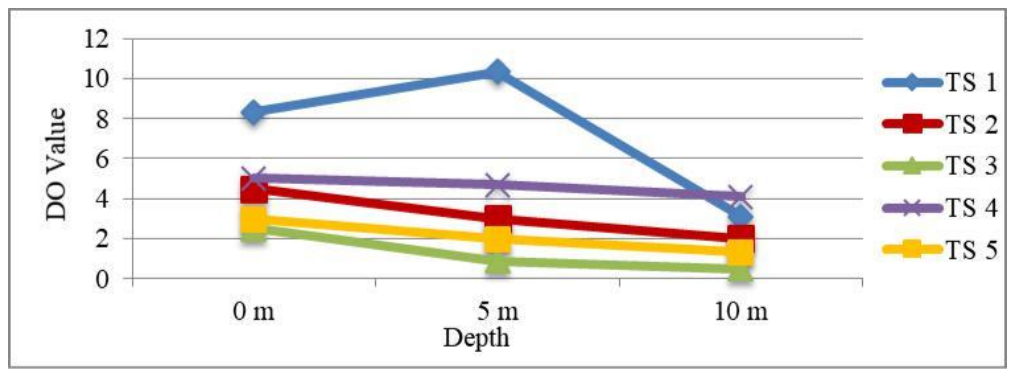

Fig. 5. Results of DO Content

Based on the results of Laboratory analysis results obtained several parameters that are not in accordance with the class II water quality standard below the minimum standard quality standard (designation of water recreation facilities and freshwater fish cultivation) including Dissolved Oxygen at sampling point II at a depth of $5 \mathrm{~m}$ and $10 \mathrm{~m}$, sampling point III and sampling point $\mathrm{V}$ at a depth of $0 \mathrm{~m}, 5 \mathrm{~m}, 10 \mathrm{~m}$.

If seen from the results of the measurement of DO values in all points with variations in the depth of $0 \mathrm{~m}, 5$ $\mathrm{m}, 10 \mathrm{~m}$, the lower DO values obtained at deeper depths. This is due to the lack of sunlight intensity that enters the bottom of the water will influence the process of photosynthesis. If photosynthesis is carried out not maximally it will cause DO in the waters to be reduced [9].

Based on figure 1.4, the DO content in the waters of the Lahor Dam in East Java can be seen at the sampling point $\mathrm{I}$ at a depth of $0 \mathrm{~m}, 5 \mathrm{~m}$ and $10 \mathrm{~m}$ can still be used for aquaculture, water recreation, livestock and to irrigate crops with a value of $8.31 \mathrm{mg} / 1,10.32 \mathrm{mg} / 1$ and $3.1 \mathrm{mg} / \mathrm{L}$. At sampling point II at a depth of $0 \mathrm{~m}$ and $5 \mathrm{~m}$ measured DO values of $4.5 \mathrm{mg} / 1$ and $3 \mathrm{mg} / \mathrm{L}$ can still meet the minimum water requirements for aquaculture. Whereas for DO values measured for $10 \mathrm{~m}$ depth of $2 \mathrm{mg} / \mathrm{L}$ cannot meet the minimum limit for feed water as aquaculture. Whereas for sampling points III and V at a depth of 0-10 m cannot meet the minimum DO standard for allotment of water as aquaculture with a range of values from $0.5-2.97 \mathrm{mg} / \mathrm{L}$. 
Exploration of Physics-Chemical Quality Lahor Reservoir of Malang District, Indonesia

From the results of the BOD analysis shown in Figure 6, it is known that the BOD value at the sampling point $\mathrm{I}$ at a depth of $0 \mathrm{~m}$ exceeds the maximum BOD value for designated waters as a place of cultivation of Tilapia with a value of $3.4 \mathrm{mg} / \mathrm{L}$. While for the depths of $5 \mathrm{~m}$ and $10 \mathrm{~m}$ can meet the maximum BOD value for class II waters with a value of $2.11 \mathrm{mg} / \mathrm{L}$ and $1.32 \mathrm{mg} / \mathrm{L}$. For the BOD value at sampling point II at a depth of $0 \mathrm{~m}$ and $10 \mathrm{~m}$, the results of the analysis were obtained with a value of $3.5 \mathrm{mg} / \mathrm{L}$ and $4.1 \mathrm{mg} / \mathrm{L}$ and could not meet the maximum BOD value for class II water. Whereas for sampling point II at a depth of $5 \mathrm{~m}$, the BOD value of $2.9 \mathrm{mg} / \mathrm{L}$ was measured and could meet the maximum BOD quality standard for class II water. The results of BOD analysis at the sampling point III at a depth of $0 \mathrm{~m}, 5 \mathrm{~m}$, and $10 \mathrm{~m}$, obtained a value that meets the maximum BOD value for class II water. The BOD value obtained from the results of laboratory analysis for sample water at IV sampling point has the highest BOD value compared to the BOD value at other points and cannot meet the maximum BOD quality standard for class II water classification with values from the surface to a depth of $10 \mathrm{~m}$ of $7.9 \mathrm{mg} /, 7.86 \mathrm{mg} / \mathrm{L}$ and $6.54 \mathrm{mg} / \mathrm{L}$. Likewise, the BOD value obtained from the analysis at the sampling point $\mathrm{V}$ cannot meet the maximum BOD quality standard for class II water classification with a value of $3.04 \mathrm{mg} / \mathrm{L}, 3.3 \mathrm{mg} / \mathrm{L}$ and $3.63 \mathrm{mg} / \mathrm{L}$.

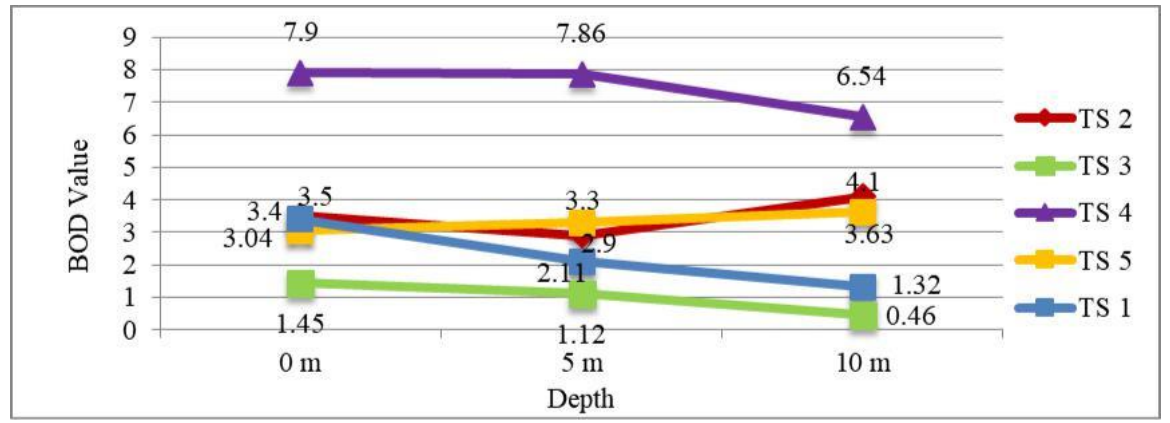

Fig. 6. Results of BOD Value

The highest BOD concentration value is at the IV sampling point which is part of the outlet of the Lahor Dam. The high BOD value at the Lahor Dam outlet is influenced by the accumulation of organic substances from several inlets and dam waters. There is a flow of water that moves towards the outlet of the dam while carrying pollutants in the form of organic matter towards the outlet and resulting in the accumulation of organic matter [10]. Organic substances that accumulate in the outlet section of the Dam undergo a process of decomposition by microorganisms found in the Dam or Lake water outlet, so that the concentration of BOD becomes high [11].

Phosphate values measured in the waters of the Lahor Dam when viewed from Figure 7 show that the value of Phosphate at each sampling point increases. The deeper the sampling water, the higher the value of Phosphate. The trend of the value applies to all sampling points. The highest value of Phosphate from the sample water analysis was $0.87 \mathrm{mg} / \mathrm{L}$ at point $\mathrm{V}$ at a depth of $10 \mathrm{~m}$. While the lowest Phosphate value is at point I of $0.58 \mathrm{mg} / \mathrm{L}$.

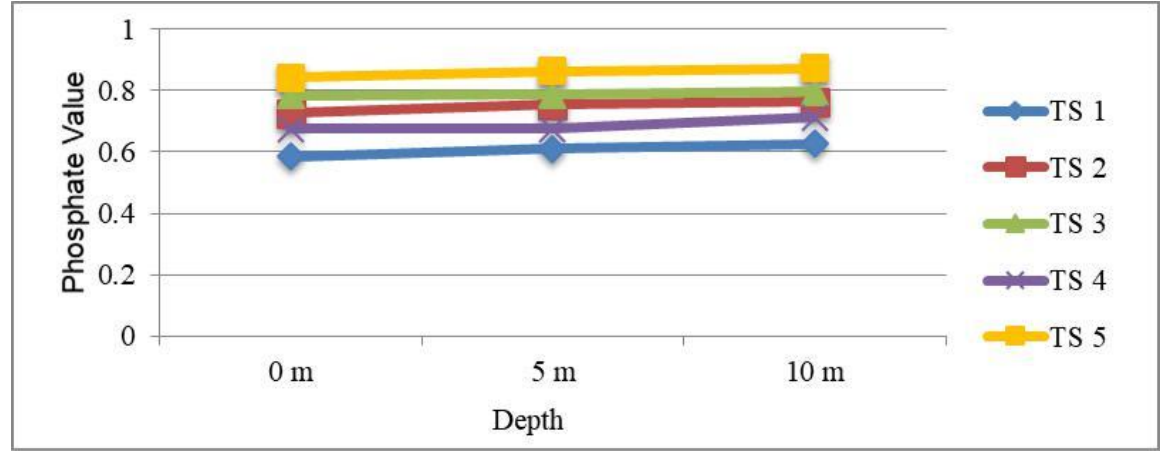

Fig. 7. Results of Phosphate Value Analysis

Phosphate values measured in the waters of the Lahor Dam when viewed from Figure 1.6 above show that the value of Phosphate at each sampling point increases in value. The deeper the sampling point, the higher the value of Phosphate measured in the waters of the Lahor Dam. The value trend applies to all sampling points. The highest value of Phosphate from the sample water analysis was $0.87 \mathrm{mg} / \mathrm{L}$ at point $\mathrm{V}$ at a depth of $10 \mathrm{~m}$. While the lowest Phosphate value is at point I of $0.58 \mathrm{mg} / \mathrm{L}$. Variations in the value of Phosphate in waters can be caused by the existence of settlement activities using detergents on the rivers around the Lahor Dam. 
H. Setyobudiarso ${ }^{1}$, E. Yuwono ${ }^{2}$ 
The measurement of the amount of Fecal Coli in the waters of the Lahor Dam was carried out at the Laboratory of Service Tirta in Malang City, East Java with the Medium Selective method in accordance with SNI 01-2332.1-2006. From the results of measurements of Fecal Coli in Lahor Dam it is known that the amount contained ranges from 1-2 MPN / $100 \mathrm{~mL}$ as shown in Figure 8.

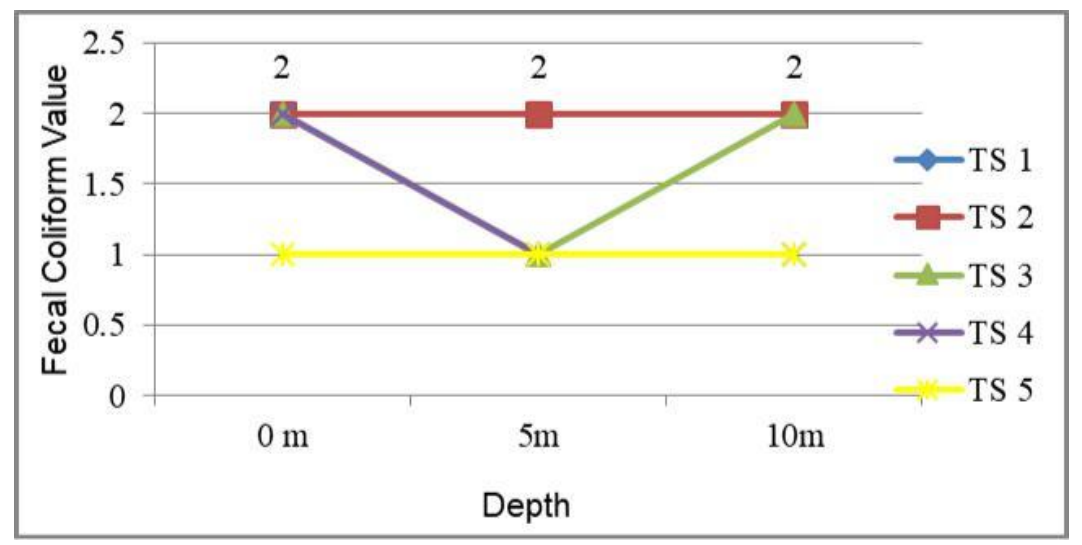

Fig. 8. Fecal Coli

The emergence of Fecal Coli bacteria in the waters of the Lahor Dam is possible to contaminate the waters of the Lahor Dam by human feces that enter the waters of the Lahor Dam through rivers whose water enters the Lahor Dam [6](Marisi, 2016). But from the data from the analysis that obtained the value of Fecal Coli from all sampling points meeting the quality standards for class I waters. This can be caused by the activities of community latrines around the river which are not many inlets of the Dam and most residents are in around the river doing toilet activities in the places provided [12]. The results of $\mathrm{pH}$ measurements at each Lahor Dam water sampling point are presented in Figure 9.

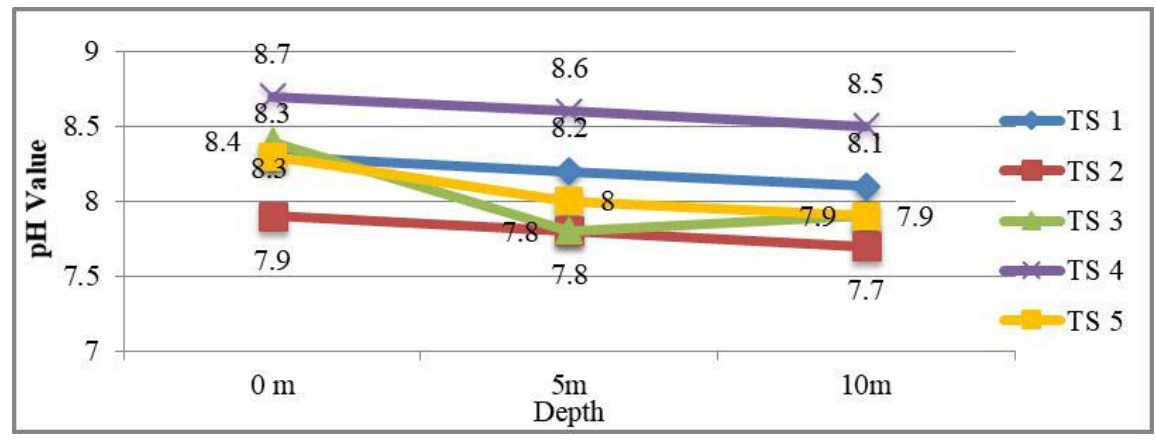

Fig. 9. Result of measurement of $\mathrm{pH}$ value

Increased acidity or $\mathrm{pH}$ values are influenced by organic and inorganic wastes which are discharged into rivers and into the waters of dams and water with a $\mathrm{pH}$ value of about 6.5-7.5 which is normal water that qualifies for an aquatic life [13]. The $\mathrm{pH}$ value in a waters can affect the dissolved oxygen content in a waters. When oxygen is in a low condition, the $\mathrm{pH}$ of the water will decrease with increasing $\mathrm{H}+$ ions in water (water tends to be acidic / $\mathrm{pH}<7$ ). The $\mathrm{pH}$ value is influenced by physical factors related to the concentration of organic materials in Lake Waters. Changes in $\mathrm{pH}$ value will affect the distribution of the distribution of microorganisms whose metabolism depends on the distribution of these chemical factors. The $\mathrm{pH}$ value will affect aquatic biochemical processes, for example the nitrification process will end if the $\mathrm{pH}$ is low [5].

\section{CONCLUSION}

The temperature in the waters of the Lahor Dam ranges from $24-28^{\circ} \mathrm{C}$ both for phytoplankton growth. Turbidity with a value of 0.4 NTU that occurs in reservoir waters or dams is caused by the entry of organic and inorganic substances and suspended sediments. DO values from surface to base have increased significantly with a value of $29.1 \mathrm{mg} / \mathrm{L}, 33.9 \mathrm{mg} / \mathrm{L}$ and $34.3 \mathrm{mg} / \mathrm{L}$ and still meet the minimum limit of aquaculture designation. The high BOD value at the Lahor Dam outlet is influenced by the accumulation of organic substances from several inlets and dam waters. The deeper the sampling water, the higher the value of Phosphate. Fecal Coli in Lahor Dam ranges from 1-2 MPN / $100 \mathrm{~mL}$ at all sampling points still meeting quality standards for class I waters. 
H. Setyobudiarso ${ }^{1}$, E. Yuwono ${ }^{2}$

\section{Acknowledgment}

The author would like to thank LPPM National Institute of Technology Malang for supporting and funding this research.

\section{REFERENCES}

[1] C. R. Goldman and A. J. Horne., Lymnology. Tokyo: Mc. Graw Hill International Book Company, 1983.

[2] H. Effendi, Telaah kualitas air, bagi pengelolaan sumber daya dan lingkungan perairan. Kanisius, 2003.

[3] A. Habibi, M. Sholichin, and E. Yuliani, "Analisa Sebaran Kualitas Air Pada Waduk Sutami Dengan Menggunakan Program WASP 7.1," Universitas Brawijaya, 2017.

[4] R. G. Wetzel, "Gradient-dominated ecosystems: sources and regulatory functions of dissolved organic matter in freshwater ecosystems," in In Dissolved organic matter in lacustrine ecosystems, Dordrecht: Springer, 1992.

[5] S. S. Brahmana and F. Achmad, "Potensi Beban Pencemaran Nitrogen, Fosfat, Kualitas Air, Status Trofik dan Stratifikasi Waduk Riam Kanan," Jurnal Sumber Daya Air, vol. 8, no. 1, 2012.

[6] K. Marisi, D. Hendrawan, and W. Astono, "Kajian Kualitas Air Waduk Kebon Melati, Jakarta Pusat," Jurnal Teknik Lingkungan, vol. 8, no. 2, pp. 155-169, 2016.

[7] A. Tessema, A. Mohammed, T. Birhanu, and T. Negu, "Assessment of physico-chemical water quality of Bira dam, Bati Wereda, Amhara region, Ethiopia.," Journal of Aquaculture Research and Development, vol. 5, no. 6, 2014.

[8] N. R. Sari, "Analisis Komparasi Kualitas Air Limbah Domestik Berdasarkan Parameter Biologi, Fisika dan Kimia di IPAL Semanggi dan IPAL Mojosongo Surakarta.,"Universitas Sebelas Maret, 2015.

[9] M. Simanjuntak, "Oksigen Terlarut dan Apparent Oxygen Utilization di Perairan Teluk Klabat, Pulau Bangka," ILMU KELAUTAN: Indonesian Journal of Marine Sciences, vol. 12, no. 2, pp. 59-66, 2012.

[10] F. D. N. Syamiazi, Saifullah, and Forcep Rio Indaryanto, "Saifullah dkk. 2015. Kualitas Air Di Waduk Nandra Kerenceng Kota Cilegon Provinsi Banten. Jurnal Akuatika. VI (2): 161-169.,” Jurnal Akuatika, vol. 6, no. 2, pp. 161-169, 2015.

[11] M. Faiz, "Peluruhan Bahan Organik Saat Musim Kemarau Pada Bagian Payau dan Laut di Muara Sungai Cisadane Tangerang, Banten.," Institut Pertanian Bogor, 2010.

[12] Muhaemi Muhaemi, R. Tuhumury, and W. Siegers, "Kesesuaian Kualitas Air Keramba Ikan Nila (Oreochromis Niloticus) Di Danau Sentani Distrik Sentani Timur Kabupaten Jayapura Provinsi Papua," The Journal of Fisheries Development, vol. 1, no. 2, pp. 45-58, 2015.

[13] W. A. Wardhana, Dampak pencemaran lingkungan. Yogyakarta: Andi Offset, 2004. 